\title{
Evaluating the influence of environmental variables on fish assemblages along Tropical Andes: considerations from ecology to conservation
}

\author{
Rafael Miranda $(\mathbb{D} \cdot$ Blanca Rios-Touma • Ana Falconí-López • Andrea Pino-del-Carpio • \\ Sergio Gaspar · Hernán Ortega • Marlon Peláez-Rodríguez • Julio Manuel Araujo-Flores • \\ Ibon Tobes
}

Received: 3 August 2020/Revised: 28 September 2021/Accepted: 14 October 2021/Published online: 29 October 2021

(C) The Author(s) 2021

\begin{abstract}
The lack of knowledge about freshwater biodiversity in remote areas like montane Andean rivers is noticeable and hinder the development of efficient conservation plans for aquatic ecosystems. Habitat requirements of tropical Andean fishes have been poorly analysed, despite the relevance of these ecological features on the fish conservation strategies. The present study aimed to examine fish assemblages along the altitudinal gradient in tropical Andean rivers and their relationship to habitat features to detect the
\end{abstract}

Guest editors: David J. Hoeinghaus, Jaquelini O. Zeni, Gabriel L. Brejão, Rafael P. Leitão \& Renata G. Frederico / Neotropical Stream Fish Ecology in a Changing Landscape.

Supplementary Information The online version contains supplementary material available at https://doi.org/10.1007/ s10750-021-04726-3.

R. Miranda $(\bowtie)$ A A. Pino-del-Carpio

Department of Environmental Biology, University of

Navarra, Irunlarrea 1, 31008 Pamplona,

Navarra, Spain

e-mail: rmiranda@unav.es

B. Rios-Touma

Grupo de Investigación en Biodiversidad, Medio

Ambiente y Salud (BIOMAS), Facultad de Ingenierías y Ciencias Aplicadas, Ingeniería Ambiental, Universidad de Las Américas, Vía Nayón S/N, Quito, Ecuador

\section{A. Falconí-López · I. Tobes}

Centro de Investigación de la Biodiversidad y Cambio

Climático (BioCamb) e Ingeniería en Biodiversidad y most relevant abiotic factors and their implication on conservation. This study was conducted on a regional scale, along six basins located in tropical Andes (500 to $2,692 \mathrm{~m}$ a.s.l.). We studied fish diversity and distribution and their habitats along these elevation gradients. We found 6,320 specimens from 53 genera. Our analysis for the six most common and widely distributed genera (Astroblepus, Brycon, Bryconamericus, Chaetostoma, Pimelodella and Trichomycterus) underlines the relevance of hydromorphological variables on fish community structure in the Andean montane rivers, whereas human alterations seem to be less significant. These findings could be useful for current management and conservation strategies considering present threats over tropical montane rivers.

Recursos Genéticos, Facultad de Ciencias de Medio Ambiente, Universidad Tecnológica Indoamérica, Machala y Sabanilla, 170301 Quito, Ecuador

S. Gaspar

Summit Asesoría Ambiental, Etxauri,

Navarra, Spain

H. Ortega

Departamento de Ictiología, Museo de Historia Natural, Universidad Nacional Mayor de San Marcos, Av. Arenales 1256, Apartado 14-0434, Lima, Perú 
Keywords Neotropical mountains - Fish fauna · Human impact · Altitudinal gradient · River connectivity $\cdot$ Environmental quality indices

\section{Introduction}

Fish biodiversity is the highest amongst the vertebrates, with about 35,500 species currently recognised, approximately the same species as that of all non-fish vertebrates combined. Amongst them, almost 18,000 fishes are freshwater-living species (Fricke et al., 2020). Despite this group's relevance in ecological and even economic and social terms (Dudgeon et al., 2006; Hermoso et al., 2018), freshwater fishes are more threatened and less known than other vertebrates (Darwall et al., 2011; Miqueleiz et al., 2020). Freshwater ecosystems are some of the most endangered globally, being lost at an alarming proportion, definitely faster than terrestrial biodiversity (Barrett et al., 2018; Reid et al., 2019).

Amongst freshwater fishes, South America is the most diverse area on earth, with around $40 \%$ of freshwater fishes occurring in the Neotropical region (Tisseuil et al., 2013; Miqueleiz et al., 2020), where indeed most of the high-priority freshwater ecoregions are located (Hermoso et al., 2017). Neotropical fishes have been studied mainly in the lowlands of major river systems, whereas montane and foothill tropical Andean fishes have been less studied (Anderson \& Maldonado-Ocampo, 2011; Tognelli et al., 2019).

\section{Peláez-Rodríguez}

Grupo de Investigación en Calidad y Preservación de Ecosistemas Acuáticos (CAPREA), Programa de Biología, Facultad de Ciencias Básicas, Universidad de la Amazonia, Carrera 11 \# 5 - 69, Barrio Versalles. Florencia, Caquetá, Colombia

\section{J. M. Araujo-Flores}

Centro de Innovación Científica de la Amazónica, Jr Cajamarca Cdra 1, Puerto Maldonado 17001, Madre de Dios, Perú

J. M. Araujo-Flores

Department of Biology and Center for Energy, Environment, and Sustainability, Wake Forest University, 1834 Wake Forest Rd, Winston-Salem,

NC 27109, USA
In the Neotropics, the Andean region retains the highest diversity of mountain fishes with almost 700 species, with a high percentage of endemic species (Encalada et al., 2019; Tognelli et al., 2019). The uniqueness of fish diversity increases with altitude in the tropical Andes (Jaramillo-Villa et al., 2010; Oberdorff et al., 2019; Jézéquel et al., 2020), making this region a hotspot on fish biodiversity. In this scenario, principal threats over aquatic ecosystems and tropical Andean fishes are deforestation, water withdrawals and pollution (Araújo-Flores et al., 2021), exotic species introduction, hydropower development, land-use and climate change (Anderson \& Maldonado-Ocampo, 2011; Lujan et al., 2013; Pelicice et al., 2017).

Despite the relevance of tropical Andean fishes, limited information exists on the distribution, conservation status, population dynamics, and habitat preferences for most of these species. Ecological and natural history knowledge of many species is scarce; several species are known only from the type locality and original description (Reis et al., 2016; Tognelli et al., 2019). Regarding their conservation status, a group of experts lead by IUCN Survival Commission evaluated 666 Andean tropical fishes (Tognelli et al., 2019). A third of assessed species were categorised as data deficient, and population trends are unknown for $77 \%$ of assessed species. Even accounting for this study, additional assessments are justified given patterns of both biodiversity and anthropogenic stressors (Hermoso et al., 2018; Ríos-Touma \& Ramírez, 2019). Although general habitat priorities are recognised-i.e. aquatic macrohabitat characteristics-, few or nothing is known about specific habitat requirements. A better understanding of fish habitat relationships is essential for designing conservation strategies and efficiently managing tropical Andean freshwater ecosystems.

Mountain fishes have been traditionally considered particularly sensitive to human impacts in water quality and quantity (Liang et al., 2013; Encalada et al., 2019; Richardson, 2019). With the subsequent exploitation of resources, human populations' growth has led to widespread decreases in the native biodiversity of mountain freshwater ecosystems (Anderson et al., 2011; Richardson, 2019). Regarding to tropical Andes, headwater streams are amongst the most likely to suffer high levels of biological diversity loss in the future, given climate change predictions and current 
impacts (Herrera-R et al., 2020). The high Andean region, specially the northern inter-Andean valleys, have a long history of high human pressure. They concentrate most of the population of the countries along the mountain range notably affecting water systems (Buytaert \& De Bièvre, 2012). It is subjected to severe agricultural land use development and deforestation that alter the landscape's capacity to provide ecological services (Leitão et al., 2018; Encalada et al., 2019). Land-use changes across the catchment and riparian zones are essential considerations in constant efforts to protect headwater streams and conserve their biodiversity. These pressures to freshwater ecosystems may also reduce the availability of ecosystem services, such as food security and nutrition, indispensable to human populations (Anderson et al., 2011; Buytaert \& De Bièvre, 2012; Lessmann et al., 2019).

Considering this high vulnerability scenario, to implement efficient management and conservation plans for freshwater systems in the region is critical. To that end, a better understanding of freshwater species ecology and diversity distribution is essential. Patterns in fish assemblage and diversification in such a hard environment as headwaters of Andes mountains arise from the interaction between habitat features and specific evolutionary constrains (Grossman et al., 1998; Carvajal-Quintero et al., 2015), providing essential considerations for riverine ecosystem conservation efforts. Nevertheless, this crucial ecological knowledge connecting environmental characteristics and fish diversity is yet scarce and dim (Alofs et al., 2014; Costa et al., 2016). Studies about habitat requirements show that mountain fish assemblages are mainly conditioned by variables related to water quality -as physicochemical parameters-, stream hydromorphology, and local habitat features (Quist et al., 2004; Li et al., 2011; López-Delgado et al., 2020). Habitat preferences of Andean mountain fishes' studies have been elaborated on in specific rivers and places, with sometimes different and controversial results (Chará et al., 2006; Alexiades \& Encalada, 2017). Therefore, we are far from understanding the habitat requirement for the majority of Neotropical mountain fish species. Tropical Andes might be subject to exceptionally high extinction risk, as it represents a hotspot with high threat status, small species ranges, and high data deficiency (Alofs et al., 2014; Pelayo-Villamil et al., 2015; Miqueleiz et al.,
2020). Knowledge about the biological and ecological requirements of species extant in this region is essential for their conservation. Studies about the Andean region's fish community structure and habitat suitability are scarce, considering specific taxon (Vélez-Espino, 2003, 2006; Chará et al., 2006) or particular basins (Jaramillo-Villa et al., 2010; Tobes et al., 2016b; Miranda et al., 2018). To our knowledge, there are no studies on fish assemblage variation about environmental features considering on a regional scale, including trans and cis-Andean basins, considering jointly different basins and rivers present on Andean mountains.

The goals of this study were (a) to examine the distribution of tropical Andean montane fishes along an altitude gradient in different freshwater ecosystems and (b) to learn which abiotic factors might be most important in determining fish assemblage and populations abundance. Our final aim is to discuss the possible implications of our results on fish conservation.

We hypothesised that specific environmental settings and human pressures strongly condition fish assemblages in the Andean region. These abiotic features can be evaluated according to the influence on fish biodiversity. Anthropogenic impacts are strongly conditioning the presence and abundance of freshwater fishes in the Andean foothill, where constraining environmental features have significantly shaped the biological characteristics and distribution of freshwater species (Lujan et al., 2013; Tobes et al., 2016a, 2016b). We anticipated that several of these abiotic factors would substantially modify the structure of river biodiversity and we aspire to find sound patterns explaining this relation along the Andean basins.

\section{Methods}

\section{Material and methods}

\section{Study area}

The present study includes 101 sampling points in six basins located in Colombia, Ecuador and Peru into the Andean mountain range $(>500 \mathrm{~m}$ above sea level, 


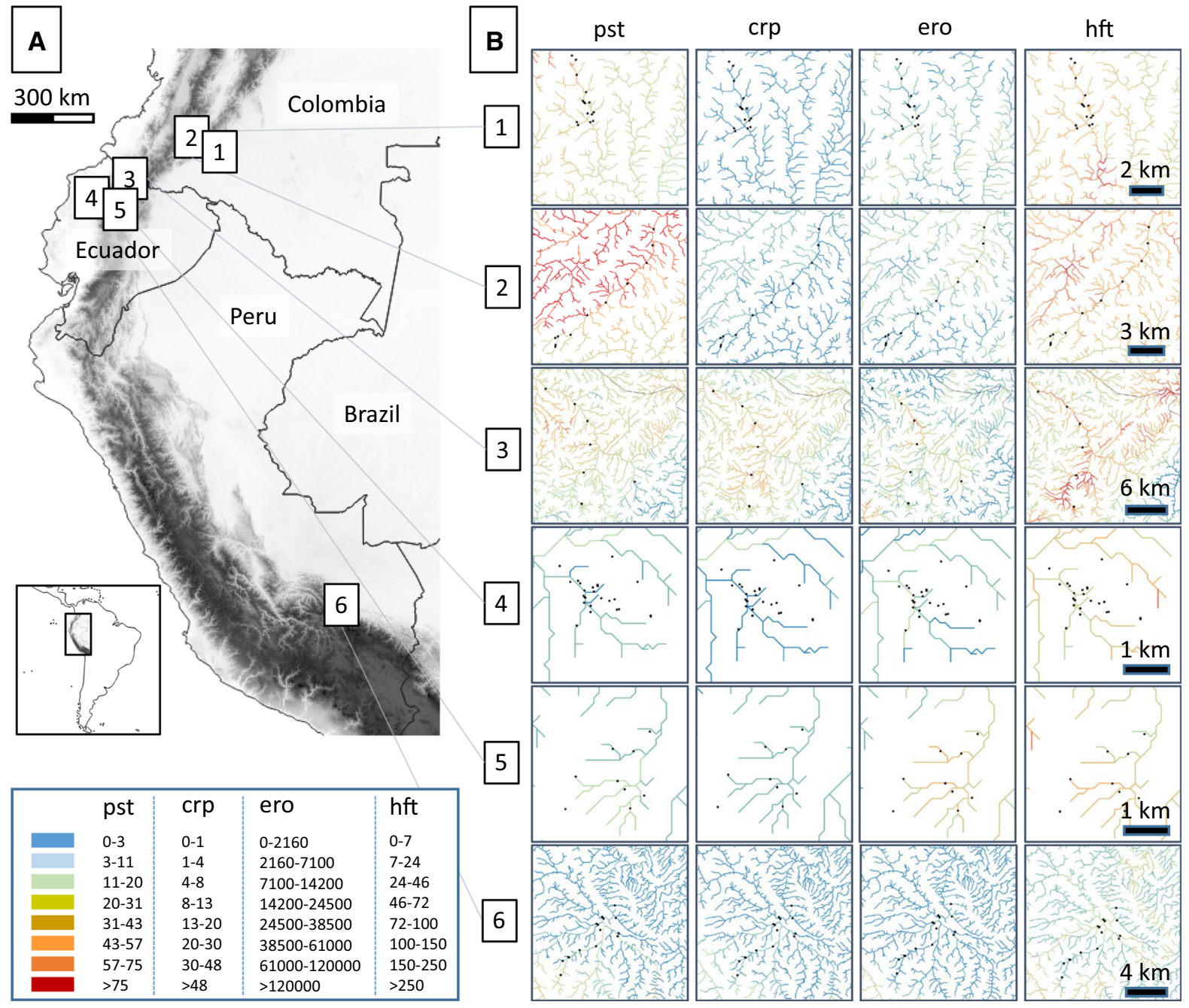

Fig. 1 A Location of the studied six basins: (1) Hacha River, (2) Suaza River, (3) Mira River, (4) Mashpi River, (5) Chirape River, and (6) Alto Madre de Dios River. B Sampling points (dark circles) and human impact indicators in the basins: pasture

Fig. 1, Annex I, Table 1). From North to South, the first basin is the Suaza River, belonging to the Magdalena Basin, which drains most Colombian Andes to the Caribbean Sea. Sampling surveys include remote-first points in the core area of the Cueva de Los Guácharos National Park (Miranda et al., 2018). The Hacha River is in the Colombian Andes too, belongs to the Caquetá River Basin, one of the largest tributaries of the Amazon River in Colombia. This river descends by the piedmont to its confluence with the Orteguaza River in the Amazonian plateau (Tobes et al., 2016b).

In Ecuador, three basins were sampled. The upper valley of the Mira River constitutes the border (pst) and cropland (crp) extend (percent cover), soil erosion rate (ero, km ha-1 year-1) and human footprint index (hft, $\times 10)$. These values were obtained from the HydroATLAS database (Linke et al., 2019)

between Colombia and Ecuador. The river continues in Colombia until the mouth into the Pacific Ocean. Mashpi and Chirape River Basins are located in the north-western Andean ridge of Ecuador (Morabowen et al., 2019). Both rivers drain on the Esmeraldas River into the North Andean Pacific Slopes-Rio Atrato freshwater ecoregion (Abell et al., 2008). Finally, Alto Madre de Dios River is the upper stretch of the Madre de Dios River, in the southwestern Peruvian Amazon, tributary of the Madeira Basin, one of the largest tributaries of the Amazon River and the unique tributary on its right riverbank with Andean influence (Benejam et al., 2018). 
Table 1 Principal characteristic of studied rivers

\begin{tabular}{|c|c|c|c|c|c|c|c|c|c|}
\hline River & Country & $\begin{array}{l}\text { Principal } \\
\text { basin }\end{array}$ & Freshwater ecoregion & Longitude & Latitude & $L$ & DA & AAF & SP \\
\hline Suaza & Colombia & Magdalena & Magdalena-Sinu & $\begin{array}{l}75^{\circ} 57^{\prime}- \\
75^{\circ} 40^{\prime} \mathrm{W}\end{array}$ & $\begin{array}{l}1^{\circ} 45^{\prime}- \\
2^{\circ} 10^{\prime} \mathrm{N}\end{array}$ & 136.0 & 1406 & 64.5 & 11 \\
\hline Hacha & Colombia & Caquetá & Western Amazon Piedmont & $\begin{array}{l}75^{\circ} 41^{\prime}- \\
75^{\circ} 31^{\prime} \mathrm{W}\end{array}$ & $\begin{array}{l}1^{\circ} 33^{\prime}- \\
1^{\circ} 51^{\prime} \mathrm{N}\end{array}$ & 50.3 & 490 & 29.7 & 16 \\
\hline Mira & Ecuador & Mira & $\begin{array}{l}\text { North Andean Pacific } \\
\text { Slopes-Rio Atrato }\end{array}$ & $\begin{array}{l}78^{\circ} 27^{\prime}- \\
77^{\circ} 53^{\prime} \mathrm{W}\end{array}$ & $\begin{array}{l}0^{\circ} 13^{\prime}- \\
0^{\circ} 52^{\prime} \mathrm{N}\end{array}$ & 145.5 & 4437 & 119.7 & 8 \\
\hline Mashpi & Ecuador & Esmeraldas & $\begin{array}{l}\text { North Andean Pacific } \\
\text { Slopes-Rio Atrato }\end{array}$ & $\begin{array}{l}78^{\circ} 55^{\prime}- \\
78^{\circ} 50^{\prime} \mathrm{W}\end{array}$ & $\begin{array}{l}0^{\circ} 08^{\prime}- \\
0^{\circ} 11^{\prime} \mathrm{N}\end{array}$ & 17.2 & 91 & 4.1 & 32 \\
\hline Chirape & Ecuador & Esmeraldas & $\begin{array}{c}\text { North Andean Pacific } \\
\text { Slopes-Rio Atrato }\end{array}$ & $\begin{array}{l}78^{\circ} 49^{\prime}- \\
78^{\circ} 44^{\prime} \mathrm{W}\end{array}$ & $\begin{array}{l}0^{\circ} 05^{\prime}- \\
0^{\circ} 13^{\prime} \mathrm{N}\end{array}$ & 19.6 & 116 & 4.9 & 11 \\
\hline $\begin{array}{l}\text { Alto Madre de } \\
\text { Dios }\end{array}$ & Peru & Madeira & Amazonas High Andes & $\begin{array}{l}73^{\circ} 30^{\prime}- \\
68^{\circ} 30^{\prime} \mathrm{W}\end{array}$ & $\begin{array}{l}11^{\circ} 00^{\prime}- \\
13^{\circ} 30^{\prime} \mathrm{S}\end{array}$ & 149.0 & 6028 & 219.9 & 16 \\
\hline
\end{tabular}

$L$ length $(\mathrm{km})$ of the main river of the sampled basin, $D A$ drainage area $\left(\mathrm{km}^{2}\right), A A F$ annual average flow $\left(\mathrm{m}^{3} \mathrm{~s}^{-1}\right) S P$ sampling points. Freshwater ecoregions, according to Abell et al. (2008). Data obtained from HydroATLAS database (Linke et al., 2019)

Sampling protocol and data acquisition

To estimate fish abundance and biomass, specimens were captured by electrofishing surveys (FEG 1500, EFKO-Elektrofischfanggeräte, Leutkirch, Germany and Hans Grassl Model IG200/ 2D, 300-600 V, 0.2-2 A, Schönau am Königssee, Germany), during the dry season between 2004 and 2017, following a single-run depletion methodology and estimation of fish abundance (Meador et al., 2003). Collected fish were anesthetised and, subsequently, counted, their total length measured and then released after the survey. The fish abundances at each sampling point were expressed as catch per unit effort (CPUE). This CPUE was calculated as the number of fishes captured in a sampling site per unit of time (Meador et al., 2003). The wadeable sampling stretches were continuous in all streams, but we ensured that principal habitat types were sampled. Surveys were performed in accordance with the procedures set out in CEN standard EN 14011 and with the corresponding authorisations from the local administrations in the different sampling campaigns.

Voucher specimens of each species were taken to the laboratory; and identified to the species level with the nomenclatural assignments according to Eschmeyer's Catalogue of Fishes (Fricke et al., 2020), or to genus level when taxonomic information was insufficient for reliable identification. Fish were identified in the laboratory using taxonomic keys and other published literature (Maldonado-Ocampo et al., 2005; Jiménez-Prado et al., 2015) as well as the collaborative efforts of A.M. Cortijo and J. Espino (Museo de Historia Natural de la Universidad Nacional Mayor de San Marcos, Lima, Peru), L.C. Chaves (Universidad de la Amazonia, Florencia, Colombia), J.I. Mojica and G. Galvis (Universidad Nacional de Colombia, Bogotá, D.C., Colombia), F. Provenzano (Universidad Central de Venezuela, Caracas, Venezuela), J. A. Maldonado- Ocampo (Pontificia Universidad Javeriana, Bogotá, D. C., Colombia), C. Carrillo, T. Pamballo (Universidad Tecnológica Indoamérica, Quito, Ecuador), J. Valdiviezo-Rivera (Instituto Nacional de Biodiversidad, Quito, Ecuador) and the authors of this article. Voucher specimens are deposited in Museo de Zoología de la Universidad Tecnológica Indoamérica, Quito, Ecuador; Instituto Nacional de Biodiversidad, Quito, Ecuador; Museo de la Escuela Politécnica Nacional, Quito, Ecuador; Museo de Historia Natural de la Universidad Nacional San Marcos, Lima, Perú; and Museo de Historia Natural de la Universidad de la Amazonía, Florencia, Colombia.

Abiotic data of the river site were measured after fish sampling. These data were categorised according to five categories. Firstly, physicochemical parameters (water temperature $\left({ }^{\circ} \mathrm{C}\right), \mathrm{pH}$, conductivity $\left(\mu \mathrm{S} \mathrm{m}^{-1}\right)$, and dissolved oxygen $\left(\mathrm{mg} \mathrm{l}^{-1}\right)$ ) were measured by digital multiparameter probes (Hanna Instruments, HI 98,129 Combo Waterpro, oximeter HI 9146, 
Table 2 Non-parametric correlation values $\left(r_{s}\right.$, Spearman rank correlation coefficient) and two-tailed probabilities (in parenthesis) that the columns are uncorrelated between abiotic variables and fish abundances (catch per unit effort, CPUE) of more representative genera in the sampling points $(N>20)$. Significant correlation coefficients $(P<0.05)$ in bold

\begin{tabular}{|c|c|c|c|c|c|c|}
\hline & Astroblepus & Bryconamericus & Chaetostoma & Brycon & Pimelodella & Trichomycterus \\
\hline \multicolumn{7}{|l|}{$\begin{array}{l}\text { Physicochemical } \\
\text { parameters }\end{array}$} \\
\hline $\begin{array}{l}\text { Water temperature } \\
\left({ }^{\circ} \mathrm{C}\right)\end{array}$ & $\begin{array}{l}-\mathbf{0 . 4 2 6 8} \\
\left(8.54 \times 10^{-7}\right)\end{array}$ & $0.2227(0.025)$ & $0.1397(0.163)$ & $\begin{array}{l}\mathbf{0 . 4 3 4 5} \\
\quad\left(5.64 \times 10^{-6}\right)\end{array}$ & $\begin{array}{l}\mathbf{0 . 4 2 1 7} \\
\quad\left(1.12 \times 10^{-5}\right)\end{array}$ & $\begin{array}{l}-0.0059 \\
(0.953)\end{array}$ \\
\hline $\begin{array}{l}\text { Conductivity } \\
\left(\mu \mathrm{S} \cdot \mathrm{cm}^{-1}\right)\end{array}$ & $0.1611(0.108)$ & $0.1191(0.236)$ & $\begin{array}{l}-\mathbf{0 . 2 2 4 7} \\
\left(2.39 \times 10^{-6}\right)\end{array}$ & $\begin{array}{l}-0.1731 \\
(0.084)\end{array}$ & $\begin{array}{l}-0.0015 \\
(0.988)\end{array}$ & $0.2704(0.006)$ \\
\hline $\begin{array}{l}\text { Dissolved Oxygen } \\
\left(\mathrm{mg} \cdot 1^{-1}\right)\end{array}$ & $\begin{array}{l}-0.1457 \\
(0.146)\end{array}$ & $\begin{array}{c}-\mathbf{0 . 2 2 6 3} \\
(0.023)\end{array}$ & $\begin{array}{l}\mathbf{0 . 5 5 4 9} \\
\quad\left(1.73 \times 10^{-5}\right)\end{array}$ & $\begin{array}{l}-\mathbf{0 . 3 3 3 9} \\
(0.001)\end{array}$ & $\begin{array}{l}-0.0071 \\
(0.944)\end{array}$ & $\mathbf{0 . 2 7 3 1}(0.006)$ \\
\hline $\mathrm{pH}$ & $\mathbf{0 . 2 3 2 0}(0.020)$ & $\mathbf{0 . 2 6 6 8}(0.007)$ & $\begin{array}{l}-0.0816 \\
(0.418)\end{array}$ & $0.1351(0.178)$ & $0.0257(0.798)$ & $0.1490(0.137)$ \\
\hline \multicolumn{7}{|l|}{$\begin{array}{l}\text { Hydromorphological } \\
\text { variables }\end{array}$} \\
\hline Mean width (m) & $\begin{array}{c}-\mathbf{0 . 2 6 3 9} \\
(0.008)\end{array}$ & $\begin{array}{c}-0.0083 \\
(0.935)\end{array}$ & $\begin{array}{l}\mathbf{0 . 6 2 5 5} \\
\quad\left(2.69 \times 10^{-12}\right)\end{array}$ & $0.1186(0.238)$ & $\mathbf{0 . 2 7 2 0}(0.006)$ & $0.0373(0.712)$ \\
\hline Mean depth $(\mathrm{cm})$ & $\begin{array}{c}-\mathbf{0 . 2 2 3 7} \\
(0.025)\end{array}$ & $\begin{array}{c}-0.1366 \\
(0.173)\end{array}$ & $\begin{array}{l}\mathbf{0 . 5 4 3 5} \\
\quad\left(4.27 \times 10^{-9}\right)\end{array}$ & $\begin{array}{c}-0.1439 \\
(0.151)\end{array}$ & $0.0458(0.649)$ & $0.0612(0.543)$ \\
\hline $\begin{array}{l}\text { Water velocity } \\
\text { average }\left(\mathrm{m} \cdot \mathrm{s}^{-1}\right)\end{array}$ & $0.0855(0.395)$ & $\begin{array}{l}-0.1150 \\
(0.252)\end{array}$ & $\mathbf{0 . 3 1 4 8}(0.001)$ & $\begin{array}{l}-0.0470 \\
(0.641)\end{array}$ & $\begin{array}{l}-0.0615 \\
(0.541)\end{array}$ & $0.0363(0.719)$ \\
\hline Shade $(\%)$ & $0.1727(0.084)$ & $0.0555(0.582)$ & $\begin{array}{l}-\mathbf{0 . 3 9 2 3} \\
\left(4.96 \times 10^{-5}\right)\end{array}$ & $0.0567(0.573)$ & $\begin{array}{l}-0.0328 \\
(0.745)\end{array}$ & $\begin{array}{l}-0.0778 \\
(0.439)\end{array}$ \\
\hline \multicolumn{7}{|l|}{ Substrate types } \\
\hline Fines $(\% .<2 \mathrm{~mm})$ & $\begin{array}{l}-0.0490 \\
(0.627)\end{array}$ & $0.0872(0.386)$ & $\begin{array}{l}-0.1045 \\
(0.299)\end{array}$ & $\begin{array}{l}-0.1860 \\
(0.062)\end{array}$ & $\begin{array}{l}-0.0576 \\
(0.567)\end{array}$ & $0.1092(0.277)$ \\
\hline $\begin{array}{l}\text { Gravels }(\% \text {. } \\
2-64 \mathrm{~mm})\end{array}$ & $0.1202(0.231)$ & $0.0193(0.848)$ & $\begin{array}{c}-0.0643 \\
(0.523)\end{array}$ & $\mathbf{0 . 2 8 9 3}(0.003)$ & $0.0430(0.670)$ & $\begin{array}{c}-0.0590 \\
(0.558)\end{array}$ \\
\hline $\begin{array}{l}\text { Pebbles }(\% \text {. } \\
\quad 64-256 \mathrm{~mm})\end{array}$ & $0.0116(0.908)$ & $0.1646(0.100)$ & $0.1346(0.180)$ & $\mathbf{0 . 2 2 9 0}(0.021)$ & $0.1226(0.222)$ & $0.1629(0.104)$ \\
\hline $\begin{array}{l}\text { Boulders } \\
\qquad(\% .>256 \mathrm{~mm})\end{array}$ & $0.1508(0.132)$ & $0.1023(0.309)$ & $\begin{array}{l}-0.0861 \\
(0.392)\end{array}$ & $\begin{array}{l}-0.0619 \\
(0.539)\end{array}$ & $\begin{array}{l}-0.0225 \\
(0.823)\end{array}$ & $\begin{array}{l}-0.1426 \\
(0.155)\end{array}$ \\
\hline \multicolumn{7}{|l|}{$\begin{array}{l}\text { Habitat quality } \\
\text { indices }\end{array}$} \\
\hline QBR & $\begin{array}{l}-0.0280 \\
(0.781)\end{array}$ & $\begin{array}{c}-\mathbf{0 . 2 3 3 9} \\
(0.019)\end{array}$ & $0.2912(0.003)$ & $\begin{array}{l}-\mathbf{0 . 4 0 4 7} \\
\left(2.69 \times 10^{-5}\right)\end{array}$ & $\begin{array}{c}-0.1807 \\
(0.071)\end{array}$ & $0.1320(0.188)$ \\
\hline IHF & $0.0180(0.858)$ & $\begin{array}{c}-\mathbf{0 . 2 3 3 9} \\
(0.019)\end{array}$ & $0.1738(0.082)$ & $\begin{array}{c}-0.1350 \\
(0.178)\end{array}$ & $0.0815(0.418)$ & $\begin{array}{l}-0.0872 \\
(0.386)\end{array}$ \\
\hline QHEI & $0.2965(0.003)$ & $\mathbf{0 . 2 7 8 2}(0.005)$ & $\begin{array}{l}-0.1368 \\
(0.172)\end{array}$ & $\mathbf{0 . 2 0 0 0}(0.045)$ & $0.0524(0.603)$ & $0.0696(0.489)$ \\
\hline \multicolumn{7}{|l|}{$\begin{array}{l}\text { Human impact } \\
\text { indicators }\end{array}$} \\
\hline $\begin{array}{l}\text { Cropland extend (\% } \\
\text { cover) }\end{array}$ & $0.1844(0.065)$ & $0.0050(0.960)$ & $\begin{array}{l}-\mathbf{0 . 3 4 0 5} \\
\left(4.95 \times 10^{-4}\right)\end{array}$ & $\begin{array}{c}-0.0226 \\
(0.823)\end{array}$ & $\begin{array}{c}-\mathbf{0 . 2 7 5 0} \\
(0.005)\end{array}$ & $0.0772(0.443)$ \\
\hline $\begin{array}{l}\text { Pasture extend (\% } \\
\text { cover) }\end{array}$ & $\mathbf{0 . 2 0 3 5}(0.041)$ & $0.1050(0.296)$ & $\begin{array}{l}-\mathbf{0 . 2 1 2 5} \\
(0.033)\end{array}$ & 0.0103 (0.919) & $0.0538(0.593)$ & $\mathbf{0 . 3 1 1 7}(0.002)$ \\
\hline $\begin{array}{l}\text { Soil erosion average } \\
\text { (kg/ha·year) }\end{array}$ & $\mathbf{0 . 2 1 2 6}(0.033)$ & $0.0984(0.328)$ & $\begin{array}{l}-0.1832 \\
(0.067)\end{array}$ & $0.0497(0.621)$ & $0.1662(0.097)$ & $0.1681(0.093)$ \\
\hline Human footprint & $0.1206(0.230)$ & $0.0530(0.598)$ & $\begin{array}{c}-0.1547 \\
(0.122)\end{array}$ & $\begin{array}{c}-0.0662 \\
(0.510)\end{array}$ & $0.1063(0.290)$ & $\mathbf{0 . 2 6 1 6}(0.008)$ \\
\hline Sampling points & 79 & 49 & 40 & 24 & 22 & 22 \\
\hline
\end{tabular}


Fig. 2 Elevation ranges and relative abundances (circles size depends on estimated abundance: catch per unit effort, fishes per hour) of genera occurring at elevations $>500 \mathrm{~m}$ a.s.l. in tributaries and main-channel sites within the studied basins

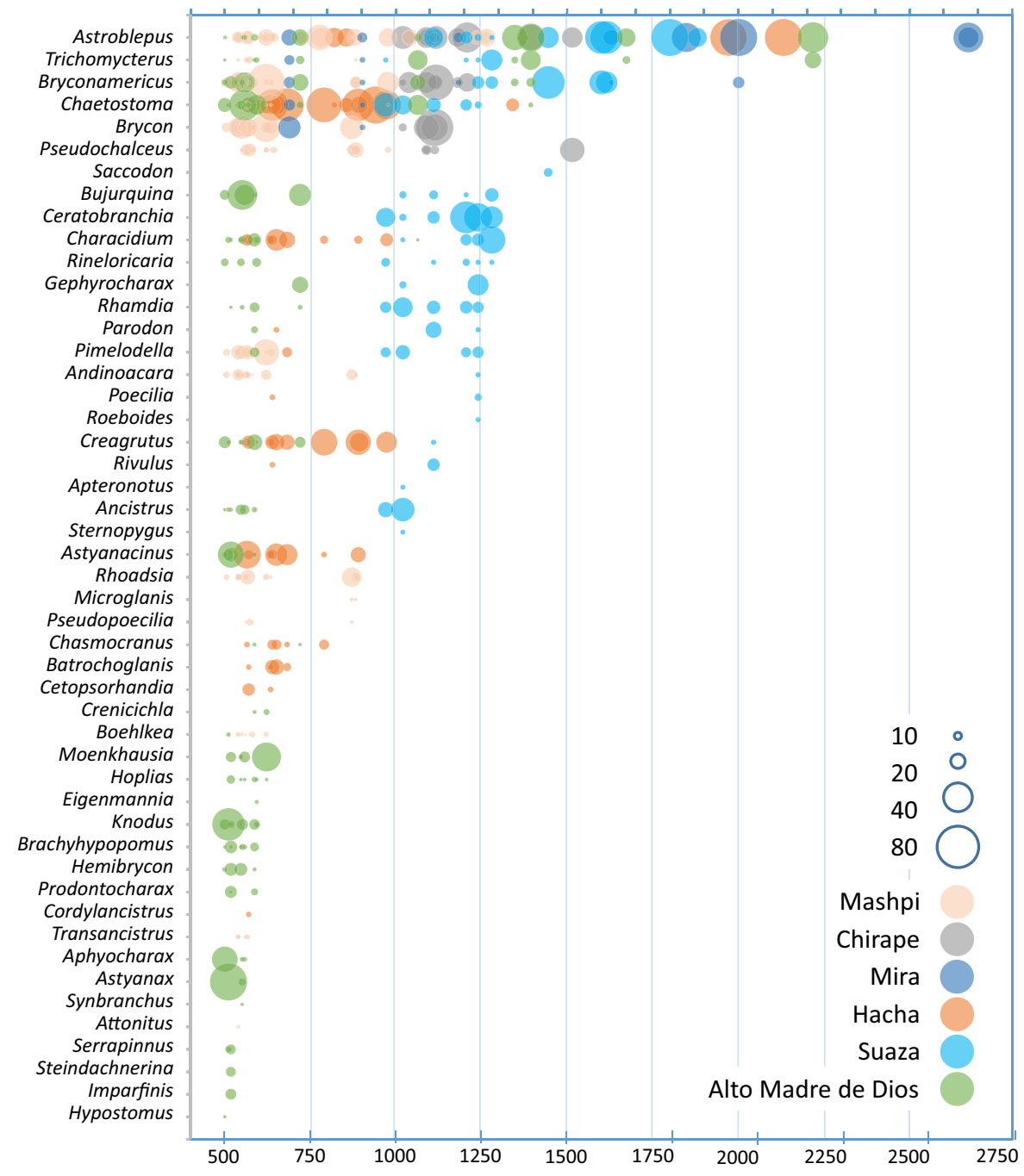

Woonsocket, RI, USA). Secondarily, hydromorphological variables (mean width $(\mathrm{m})$, mean depth $(\mathrm{cm})$, water velocity $\left(\mathrm{m} \mathrm{s}^{-1}\right)$, percentage of shade) were estimated in each sampling points. Thirdly, in the same places were estimated the percentage of substrate types (fines, $<2 \mathrm{~mm}$; gravels, 2-64 mm; pebbles, 64-256 mm; boulders, $>256 \mathrm{~mm}$; bedrock). These values were determined along perpendicular transects to the flow at approximately 5-m intervals. Along each transect, we measured width (considering only wetted surface), water depth and water velocity, and determinate if the point was shaded or not, and the type of substrate at 1-m intervals, according to fish habitat assessment protocols (Simonson et al., 1994). Shading (\%) was visually estimated to nearest $10 \%$, and considering shade when the sun is at its zenith $\left(90^{\circ}\right.$ above the horizon). Water velocity was measured with a rheometer (manufactured, boat display SpeedCoach OC 2, Nielsen-Kellerman Co., Boothwyn, PA, USA).

Fourth, three habitat quality indices were measured: the qualitative habitat evaluation index QHEI (Gazendam et al., 2011), the Index of Fluvial Habitat IHF and the Riparian Forest Quality Index QBR adapted to Andean mountains (Acosta et al., 2009). The QHEI jointly considers different habitat parameters related to substrate and embeddedness, river hydromorphology (instream structure, water speed and depth, morphological diversity), riparian vegetation cover and channel alteration. The IHF characterises the physical habitat and evaluates the relationship between habitat heterogeneity and the stream channel's physical variables, which are 


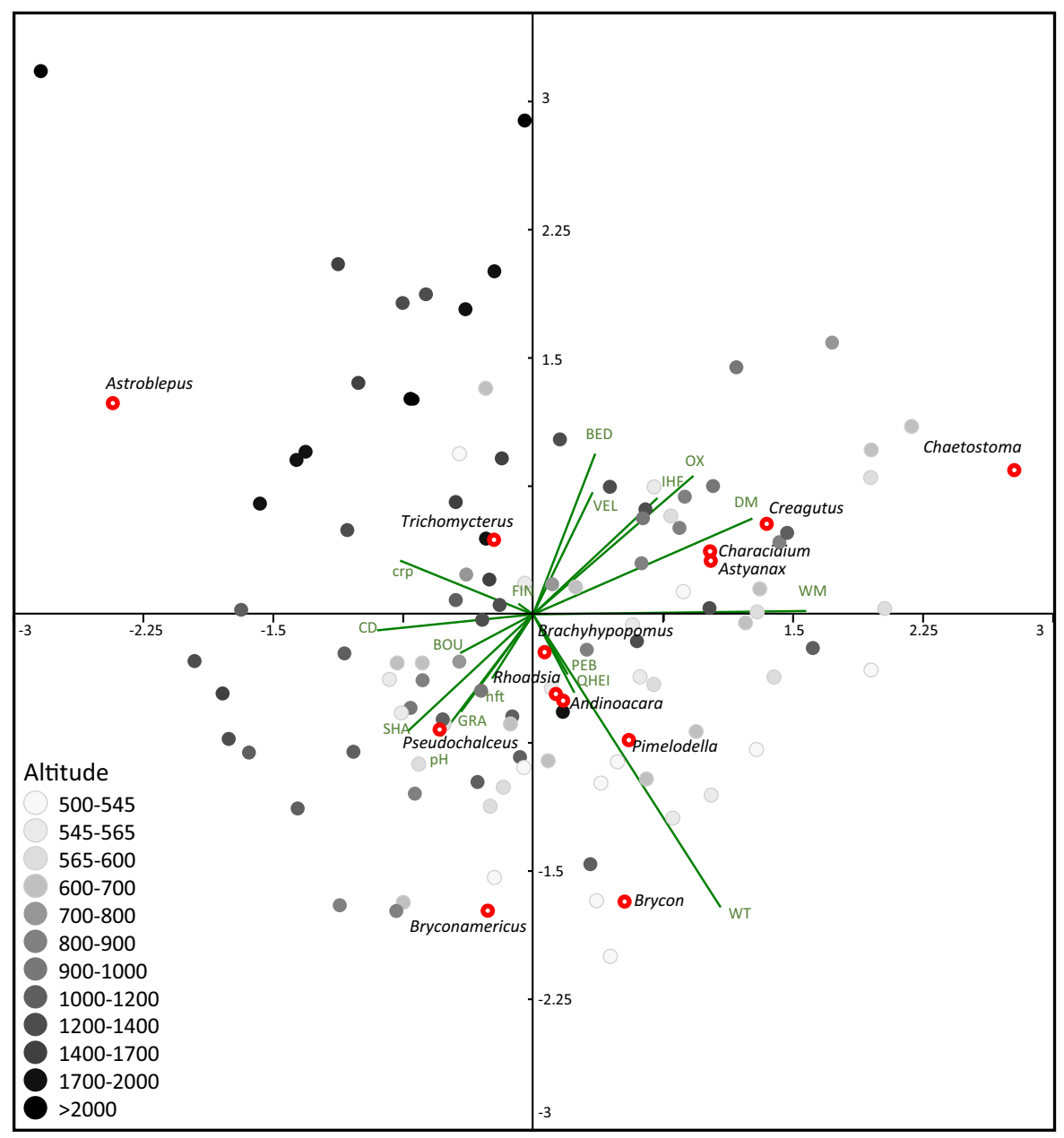

Fig. 3 Redundancy analysis biplot for the sampling sites scores (grey circles) and fish genus scores (red circles). Abiotic variables (green vectors) are plotted as correlations with fitted site scores, and their length is proportional to the explained variability. $W T$ water temperature $\left({ }^{\circ} \mathrm{C}\right), O X$ dissolved oxygen

influenced by hydrology and substrate composition. The IHF considers the substrate diversity and embeddedness, the sedimentation in pools, the frequency of riffles and the diversity of flow velocity and depths. The index also evaluates other elements that contribute to increasing physical habitat diversity, as the presence and dominance of different groups of aquatic vegetation, accumulation of leaves and drifted wood (Acosta et al., 2009).

The QBR index considers aspects of the riparian forest, including canopy cover and structure and channel alterations. The QBR is calculated in the field by a field surveyor (an 'observer') who is familiar with the most common tree and shrub species found in the $\left(\mathrm{mg} \cdot \mathrm{l}^{-1}\right), C D$ conductivity $\left(\mu \mathrm{S} \cdot \mathrm{cm}^{-1}\right), \mathrm{pH}, W M$ mean width $(\mathrm{m})$, $D M$ mean depth $(\mathrm{cm}), V E L$ water velocity $\left(\mathrm{m} \cdot \mathrm{s}^{-1}\right), F I N$ fines, $G R A$ gravels, $P E B$ pebbles, $B O U$ boulders, $S H A$ shade (\%), $I H F$ Index of Fluvial Habitat, QHEI Qualitative Habitat Evaluation Index, crp cropland extend, $h f t$ human footprint index

study areas. The index must be calculated in river or stream lengths of $50 \mathrm{~m}$ (upstream areas) or $100 \mathrm{~m}$ (middle and lower reaches). Both river banks and analysed upstream or downstream from observer should be considered together.

This index is a summation of four parts: (1) the percentage of riparian cover of all kind of plants except annuals; (2) the structure and rate of forest cover, including shrubs and other low-lying vegetation; (3) the quality of this cover, considering native and non-native tree species and the percentage of gallery-type structure; and (4) the naturalness of the river channel, according to morphological changes for human activity, channel reduction, river linearisation 
and elimination of meanders. These differences are measured in a simple, quantitative way according methodology explained in Munné et al. (2003). The index varies between 0 and 100 points, and it is the sum of these four scores.

Finally, to examine the effect of human activity, four indicators of impacts were considered (Fig. 1): the cropland and pasture extent, the soil erosion and the human footprint. As percent cover in the total watershed upstream of reach pour point, the extension of pastures and croplands is a good indicator of human development and impact. EarthStat provides a global data set of croplands and pastures circa 2000 by combining agricultural inventory data and satellitederived land cover data (Ramankutty et al., 2008). Soil erosion rates expressed as a mass of soil lost per unit area and time $\left(\mathrm{km} \mathrm{ha}^{-1}\right.$ year $\left.^{-1}\right)$ measure land-use changes and human impact. These rates were estimated using a combination of remote sensing, GIS modelling and census data (Borrelli et al., 2017). Finally, the accumulated Human Footprint index in the total watershed upstream of the reach pour point was considered. The Human Footprint represents the relative human influence. This index considers different human pressures: (1) built environments, (2) population density, (3) electric infrastructure, (4) croplands, (5) pasture lands, (6) roads, (7) railways, and (8) navigable waterways. These human impacts were combined in a unique index, the Human Footprint (Venter et al., 2016). These values were obtained for each point from the HydroATLAS database, a global compilation of hydro-environmental river reach characteristics at 15 arc-second resolution (Linke et al., 2019).

\section{Statistical analysis}

Analyses were conducted at two levels. At the basic level, we carry out an exploratory analysis based on non-parametric correlations (Spearman's rho) amongst the abiotic variables and fish abundances of more representative species (present in all the basins and collected in more than 20 places). The relationships between fish assemblages and abiotic explanatory variables were explored at sampling points by redundancy analysis. Redundancy analysis is a constrained ordination method, similar to multiple regressions. It estimates the amount of variation in multiple dependant variables based on multiple predictor variables (Legendre \& Legendre, 1998).

To carry out the redundancy analysis, environmental variables, except $\mathrm{pH}$, were log-transformed (ln $x+1)$ to improve normality and because they were measured using different units. According to the recommendation of this method, logit transformation was used too for percentage data to analyse proportions in ecological research as an alternative to the arcsine square root transformation (Warton \& Hui, 2011). Posteriorly, these variables were submitted to a Spearman correlation to identify multicollinearity. In the case of redundant variables $\left(r_{\mathrm{s}}>|0.60|, P<0.05\right)$, those with higher predictive importance for tropical stream fish assemblages, according to the literature, were retained (Prudente et al., 2017). Data on fish abundance were root transformed.

To reduce the influence of rare species on multivariate analyses, poorly represented species (occurring at only ten sites) were removed from this analysis, and taxa were grouped by genus. Because of the low representativeness of many species, data disaggregation to species level causes a severe loss of information. Grouping species into genera allows a more consistent analysis of the obtained data. The significance level was set at $P=0.05$. Statistical analyses were conducted with the PAST 4.05 statistical software (Hammer et al., 2001).

\section{Results}

A total of 6,320 specimens were considered in this study from 101 surveys carried out in the Tropical Andes ( $>500 \mathrm{~m}$ above sea level). From them, seventy-four species were identified, whereas 2,065 specimens (32.7\% of the total catch) belonging to 25 genera were not identified until the species level (Annex II displays the number of specimens collected per sampling points). Because of the high proportion of unidentified specimens until species level, posterior analyses have been performed grouping species on genus level. These species are clustered on 53 genera, distributed between 500 and 2,692 $\mathrm{m}$ of elevation (Fig. 2).

Only six genera (Astroblepus, Brycon, Bryconamericus, Chaetostoma, Pimelodella and Trichomycterus) were extant in all the basins and more than 20 surveys, being the climbing catfishes (genus 
Astroblepus) the most frequent species, present on 79 of 101 sampling points and distributed in all the altitudinal ranges. The representative genera of our analyses show a significant correlation between abiotic variables and fish abundances in different ways, depending on genera (Table 2). The climbing catfishes show the most distinct pattern compared to other genera. Whereas this genus shows preference to cold waters and narrow and shallow stretches, other genera show a positive correlation with the increase of temperature (Bryconamericus, Brycon and Pimelodella) and morphological variables as width and depth (Chaetostoma and Pimelodella). Estimated fish abundances do not show a significant relationship with substrate types, except for genus Brycon, positively correlated to the presence of gravels and pebbles (Table 2; Fig. 3).

Regarding multicollinearity of abiotic variables, significant Spearman correlation values $\left(r_{\mathrm{s}}>|0.60|\right.$, $P<0.05)$ were observed for dissolved oxygen (OX) in relation to the Riparian Forest Quality Index (QBR) $\left(r_{\mathrm{s}}=0.75\right)$; Human Footprint (HFT) in relation to pasture extent (PST) and soil erosion (ERO) $\left(r_{\mathrm{s}}=0.70\right.$ and $\left.r_{\mathrm{s}}=0.66\right)$. The variables $\mathrm{OX}$ and HFT were retained in redundancy analysis. Finally, we select 17 environmental variables, including four physicochemical parameters (water temperature, $\mathrm{pH}$, conductivity and dissolved oxygen), four hydromorphological variables (mean width, mean depth, water velocity, and percentage of shade), two habitat quality indices (QHEI and IHF), five substrate types, and two human impact indicators (cropland extent and the human footprint).

The total fraction of the variance explained by the redundancy analysis was $39.4 \%$. The first two canonical axes explained $17.5 \%$ and $10.8 \%$ of the data variance, respectively. The redundancy analysis's first axis was principally influenced by hydromorphological variables (mean width and mean depth of sampling points) and physicochemical parameters (water temperature, conductivity and dissolved oxygen). In contrast, the water temperature was again the primary determinant of assemblage structure along the second axis, and additionally, other variables as the percentage of bedrock substrate, dissolved oxygen or water velocity (Fig. 3).

Climbing catfishes (genus Astroblepus) are separated from the remaining, and they are closely related to high mountain stretches of the rivers, with lower temperatures and higher environmental quality indices. The pencil catfishes (genus Trichomycterus) appear in a second position regarding altitude (Fig. 2). They are shown with climbing catfishes in the upper river stretches of high mountains. Three genera of characoids (Bryconamericus, Brycon and Pseudochalceus) are the next genus in the altitudinal gradient, related to the presence of gravels and rocky substrates, high $\mathrm{pH}$ values, and shadow places. In places with lower elevations, armoured catfishes of the Chaetostoma genus and other genera are related to more profound and wider river stretches (Table 2; Fig. 3).

Regarding the human impact indicators, cropland and pasture extent are negatively correlated with some genera (Chaetostoma and Pimelodella), showing their preference for low-impact places (Table 2). However, climbing and pencil catfishes (Astroblepus and Trichomycterus genus, respectively), the inhabitants of the highest areas (Fig. 2), exhibit a positive correlation with pastures, as well as a positive association with the soil erosion in the case of Astroblepus, and with the human footprint in the case of Trichomycterus. These two genera are related to cropland extent in the redundancy analysis (Fig. 3).

\section{Discussion}

Fish beta-diversity in the Andes is higher than for other montane places in the world because of the particular evolutionary process in the Neotropical montane fishes (Schaefer \& Arroyave, 2010; Oberdorff et al., 2019; López-Delgado et al., 2020). Ninetynine taxa (seventy-four species, twenty-five undetermined) were registered in this study, in addition to a high percentage of endemic taxa (Annex II). Whereas at headwaters only few but endemic species are present, the number of species grows downstream, according to the ordinary succession of fish species in the Andean elevation gradient (Lujan et al., 2013) (Fig. 2). The increase in habitat diversity, environmental stability and trophic resources from upstream to downstream cause the rise in species, as it has been widely reflected in the literature (Carvajal-Quintero et al., 2015; Benejam et al., 2018).

Ecological attributes determine fish assemblages in freshwater ecosystems and show diverse relationships amongst them. According to previous studies, analysed fish populations are distributed through 
altitudinal gradient depending on habitat characteristics (Fig. 2), from torrential headwater to moderate current in the intermediate places on the piedmont, between mountain upstream, and lowland reaches (Jaramillo-Villa et al., 2010; Encalada et al., 2019). Regarding substrate preferences, tropical Andean rivers present in general rocky substrates, increasing the diversity of sizes downstream by the erosion effect, offering shelter to mountain fish species and their principal food resources (Anderson \& MaldonadoOcampo, 2011; Lujan et al., 2013; Miranda et al., 2018).

Redundancy analysis presents similar results regarding fish distribution in the altitudinal gradient and their relationships with abiotic variables (Fig. 3). Vector direction and length of environmental variables in this analysis indicate the relative magnitude and influence of a particular variable on the fish assemblages (Borcard et al., 2011). Water temperature is considered one of the most relevant factor conditioning river fish assemblages, widely discussed in the literature (Kriaučiūnienè et al., 2019; Moody et al., 2019). In mountain ecosystems, the variation of temperature across the elevation gradient determines more remarkably the local patterns of fish populations (Carvajal-Quintero et al., 2015; Reis et al., 2016). Water temperature directly affects the metabolism, growth and fecundity of fishes, and it is considered one of the most important factors limiting fish assemblages in high elevated places (Tejerina-Garro et al., 2005; Jaramillo-Villa et al., 2010). Mountain ecosystems show low metabolism rates due to cooler habitats, and only fishes adapted to low growth and fecundity rates, principally invertivore species, can survive in the highest elevations (Román-Valencia, 2001; Benejam et al., 2018), whereas fish diversity, richness and abundance increase in lower altitudes because of habitat diversification and the rise in metabolism (Jaramillo-Villa et al. 2010; Carvajal-Quintero et al., 2015).

However, whereas dissolved oxygen concentration should be negatively correlated with water temperature, the highest elevation places $(>1,000 \mathrm{~m}$ a.s.l.) show low levels of dissolved oxygen (Fig. 3) due to low partial pressures of atmospheric oxygen at high mountain altitudes (Lujan et al., 2013). This lack of oxygen and low temperatures in the highest places could determinate the presence of only adapted species because of low metabolism (Moody et al., 2019; Cornejo et al., 2020).

Hydromorphological variables are considered relevant on fish habitat relationships too: steep stretches with the abundance of rocky substrates and speedywaters impede the access of predators and promote the presence of adapted running-water species. Besides, shadow-water shores are used as refuges for juveniles of some species. On the other hand, the existence of pools permits the occurrence of other bigger species (Jaramillo-Villa et al., 2010; Lujan et al., 2013).

Our results highlight the relevance of these hydromorphological variables on fish community structure in the Andean montane rivers; scores of redundancy analysis indicate which environmental variables are significant in determining the fish community composition (Braak \& Verdonschot, 1995). Unexpectedly, the direct human impact seems to be less critical (Table 2; Fig. 3). Furthermore, climbing (Astroblepus) and pencil (Trichomycterus) catfishes present a positive correlation with some human impact indicators (Table 2; Fig. 3). These correlations highlight the capacity of these genera to subsist in high impacted places; their abundances are more conditioned by other variables than human activities, as will be discussed later.

Although these high correlations with some types of human alterations on the basin territory of these genera, our studied basins do not have substantial modifications compared to other basins in the Andean region. Obviously, artificial changes as cropland and pasture development or urban expansion and pollution have definitely adverse effects on fish conservation (Fu et al., 2003; Leitão et al., 2018). However, some representative montane species have been localised in highly impacted places in the present study and others. Fish biodiversity seems to be more conditioned by hydromorphological characteristics than anthropic alterations. In a recent study, positive relationships amongst highly modified agricultural streams and abundances of the climbing catfish Astroblepus vaillanti (Regan, 1904) have been found (Alexiades \& Encalada, 2017). Authors conclude that A. vaillanti distribution might be driven by an invasive predator displacement, looking for refuges in the altered places. Other researchers found that variables associated mainly with river size and substratum structure were significant determinants of fish assemblage (Chará et al., 2006; Rodrigues-Filho et al., 2017). In addition, 
the climbing catfish Astroblepus mariae (Fowler, 1919) was detected in high-altered places, where morphological features of the creeks determine fish distribution (Buitrago-Suarez et al., 2015). In other regions, fish community structure is related to water quality and habitat structure variables, but mainly to hydromorphological features ( $\mathrm{Li}$ et al., 2011; Tobes et al., 2016a).

Climbing catfishes are the most common genus in this study, showing the highest abundance and occurrence values, and reaching the highest elevated places (along with pencil catfishes only for the Alto Madre de Dios Basin, Fig. 2). Astroblepus is the principal representative fish genus of the Andes' high mountains, widely distributed from Panama to Bolivia, being the unique species present at sites close to the headwaters (Schaefer \& Arroyave, 2010; Benejam et al., 2018). This genus is particularly adapted to steep-torrential streams with a rapid current, using these stretches as refuges from predators, and using local food resources (Pouilly et al., 2006; Lujan et al., 2013). The knowledge of this genus is scarce in general, especially concerning biogeography and systematics (Schaefer \& Arroyave, 2010; DoNascimiento et al., 2017). Regarding conservation status on the Astroblepus species, most of the information available is for only one species, A. ubidiai Pellegrin, 1931, in the Mira River Basin (Vélez-Espino, 2003, 2005, 2006). This species is catalogued as critically endangered by IUCN Red List, considering the total area of occupancy, the subpopulation's fragmentation, and the environmental deterioration (water extraction, pollution, habitat loss, fishing and invasive specie's impact). Although the distribution and population's status of most Astroblepus species is unknown, general threats over A. ubidiai are generalised on the Andes (Arratia, 1983; Román-Valencia, 2001). It is expected similar conservation status than A. ubidiai for other species of this genus (RománValencia, 2001; Buitrago-Suarez et al., 2015; Alexiades \& Encalada, 2017). Their restricted distributions, limited dispersal capacity, high adaptation to extreme environmental conditions, and the preference of invasive trout for those habitats (Vimos et al., 2015) increase the probability to categorise these fishes as threatened (Anderson \& Maldonado-Ocampo, 2011).

As discussed above, the hydromorphological features of Andean mountain streams are especially relevant to the habitat requirements of these fish species (Table 2; Fig. 3). However, habitat alteration has been poorly studied in the Andean montane streams, despite the broad knowledge of these impacts (Encalada et al., 2019; Richardson, 2019). The adverse effects of these alterations on mountain headwaters, as the development of small obstacles, can be similar to those reported for larger dams regarding fish diversity conservation (Alexandre \& Almeida, 2010; Tobes et al., 2016a). One of the main consequences of constructing these small obstacles is the hydromorphological modification of stretches, affecting fish communities (Tobes et al., 2016a; Latli et al., 2019). Similarly, other habitat alterations as channelisation or dredging produce significant modifications on fish assemblages (Fischer et al., 2012; Reis, 2013; Chiu \& Suen, 2016).

To our knowledge, before this study, there was little published information on the Andean montane fishes and habitat relationships, and most of the research was conducted mainly considering a particular species (Vélez-Espino, 2003, 2006; Chará et al., 2006) or certain places and basins (Jaramillo-Villa et al., 2010; Tobes et al., 2016b). With our analysis, regional ecological patterns explaining habitat preference arise, and we through some light on the main drivers for fish distribution and assemblage composition. Whereas taxonomic determination is the first step on species conservation, knowledge of population trends, ecological features, and principal threats are necessary to determine the conservation status of those species (Araújo-Flores et al., 2021). Fish habitat is a key component to delimit these statuses and develop successful conservation plans (Costa \& Barletta, 2016; Tognelli et al., 2019).

Finally, some considerations should be discussed regarding the lack of knowledge and the known taxonomic impediment (Giangrande 2003; Donaldson et al., 2016). In this study, taxonomic experts were not able to identify until a species level a third of the studied specimens. Whereas taxonomists' expertise is beyond any doubt, the lack of knowledge explains the incapacity to identify these species (Tognelli et al., 2019; Miqueleiz et al., 2020). For this reason, species are grouped in genera in the analyses. However, different species belonging to one genus can show different habitat preferences (Anderson \& Maldonado-Ocampo, 2011). For example, pencil catfishes of genus Trichomycterus include more than 170 species, with current high description rates and complex 
taxonomic history (Donin et al., 2020). Species of this genus are present in the entire South American continent, from sea level to $>4,000 \mathrm{~m}$ of altitude, using different habitats and resources (Chará et al., 2006). These specific differences should be taken into consideration in the interpretation of our results. Whereas general habitat preferences of mountain species could be considered for most species of a genus (Anderson \& Maldonado-Ocampo, 2011), some species present habitat adaptations that could differ from our results.

Most species of studied taxa have complex taxonomic relationships that are currently unclear, and researchers are not in full agreement about their taxonomic status (Lessmann et al., 2016). The uncertainty and complexity of Neotropical freshwater fish's taxonomy (Hubert \& Renno, 2006; Olden et al., 2010) highlight the necessity to increase resources of taxonomists with relevant and high-quality skills in this area, as essential knowledge on ecological and conservation biology (Giangrande, 2003; Mace, 2004). Deficient taxonomic data (the Linnean shortfall) is a severe and general impediment on environmental studies in the Neotropical region (Collen et al., 2008; Anderson \& Maldonado-Ocampo, 2011).

\section{Conclusions}

Our results show that variability in hydromorphological variables has relevance to the habitat requirements of tropical Andean fishes. River morphology configures the distribution and fish assemblage in these mountain ecosystems. Our study underlines the significance of hydromorphological variables on fish community structure in the area, whereas human alterations seem to be less significant. Our results suggested that the conservation of tropical Andean fishes requires maintaining habitat heterogeneity on a regional scale. These findings could assist in local management and conservation activities and be helpful in a global conservation assessment of Andean fishes, considering current threats over hydromorphology and general habitat features of tropical montane rivers. However, more data are needed to determine habitat fish relationships in the montane tropical Andes, allowing better strategies to conserve fish diversity in these aquatic ecosystems. There is a serious need to increase scientific knowledge and effective conservation of this fauna and other biodiversity living in freshwater montane tropical Andes and other upland regions.

Acknowledgements The authors are grateful to A. Escobar, D. Godoy, Y.A. Jara, A. Morabowen, E. L. Morabowen K. U. Osorio, C. A. Ospina, H.A. Peláez, A. Quispe, Y.M. Salas, I. Sandoval and D. Sierra, for their invaluable field assistance and friendship. We thank the collaborative efforts of J. I. Mojica and G. Galvis (Universidad Nacional de Colombia, Bogotá, D.C., Colombia), A.M. Cortijo and J. Espino (Departamento de Ictiología del Museo de Historia Natural de la Universidad Nacional de San Marcos, Lima, Perú), F. Provenzano (Universidad Central de Venezuela, Caracas, Venezuela) and J. A. Maldonado-Ocampo (Pontificia Universidad Javeriana, Bogotá, D.C., Colombia) for their assistance with species identification. We are grateful for the unreserved cooperation of H. Pepper, who provided logistic and data support. The authors are grateful to the Asociación de Amigos-University of Navarra, which awarded a doctoral grant to Ibon Tobes (2012-2014). Universidad Tecnológica Indoamérica provided resources for field trips and material processing for Mashpi, Chirapi and Mira Watershed sampling. Thanks to Parque Nacional Cueva de los Guacharos for research authorization and to Ministerio del Ambiente of Ecuador for the sampling permit (MAE-DNB-CM-2015 - 0017, 008-2016-IV-FAUDPAP-MA). Mashpi Biodiversity Reserve, Mashpishungo and Pambiliño Reserves, besides preserving amazing Choco Andean rivers, provided facilities, knowledge and assistance during fieldtrips in Ecuador. The Asociación para la Conservación de la Cuenca Amazónica (ACCA), kindly provided valuable information, collaboration and lodging during our fieldwork. This study was sponsored by the fellowship program III-B of the Ministry of External Affairs (MAEC-AECID), and the fellowships program for mobility of senior professors and researchers to foreign academic and research centres, Ministry of Education and Vocational Training of the Government of Spain (2019). Blanca Rios-Touma had the support of project AMB.BRT.20.01 (UDLA). The vice-rectory of research of the Universidad de la Amazonia provided logistic and economic resources for the achievement of this work.

Author contributions RM, BR-T, IT, HO, MP-R, SG and JMA-F conceived and designed the analyses, all authors collected the data, HO, IT, SG and JMA-F coordinated the identification of the specimens, RM and IT performed the analyses, RM, BR-T, AF-L, JMA-F and IT wrote the paper.

Funding Open Access funding provided thanks to the CRUECSIC agreement with Springer Nature. The Asociación de Amigos-University of Navarra awarded a doctoral grant to Ibon Tobes (2012-2014). This study was sponsored by the fellowship program III-B of the Ministry of External Affairs (MAECAECID), and the fellowships program for mobility of senior professors and researchers to foreign academic and research centres, Ministry of Education and Vocational Training of the Government of Spain (2019). Blanca Rios-Touma had the support of project AMB.BRT.20.01 (UDLA). The vice-rectory 
of research of the Universidad de la Amazonia provided logistic and economic resources for the achievement of this work.

Data availability Data used for this analysis are included on the supplementary material.

\section{Declarations}

Conflict of interest There are not any conflict of interest or competing interests.

Open Access This article is licensed under a Creative Commons Attribution 4.0 International License, which permits use, sharing, adaptation, distribution and reproduction in any medium or format, as long as you give appropriate credit to the original author(s) and the source, provide a link to the Creative Commons licence, and indicate if changes were made. The images or other third party material in this article are included in the article's Creative Commons licence, unless indicated otherwise in a credit line to the material. If material is not included in the article's Creative Commons licence and your intended use is not permitted by statutory regulation or exceeds the permitted use, you will need to obtain permission directly from the copyright holder. To view a copy of this licence, visit http://creativecommons.org/licenses/by/4.0/.

\section{References}

Abell, R., M. L. Thieme, C. Revenga, M. Bryer, M. Kottelat, N. Bogutskaya, B. Coad, N. Mandrak, S. C. Balderas, W. Bussing, M. L. J. Stiassny, P. Skelton, G. R. Allen, P. Unmack, A. Naseka, R. Y. Ng, N. Sindorf, J. Robertson, E. Armijo, J. V. Higgins, T. J. Heibel, E. Wikramanayake, D. Olson, H. L. López, R. E. Reis, J. G. Lundberg, M. H. Sabaj Pérez \& P. Petry, 2008. Freshwater ecoregions of the world: a new map of biogeographic units for freshwater biodiversity conservation. BioScience 58: 403-414.

Acosta, R., B. Ríos, M. Rieradevall \& N. Prat, 2009. Propuesta de un protocolo de evaluación de la calidad ecológica de ríos andinos (CERA) y su aplicación a dos cuencas en Ecuador y Perú. Limnetica 28: 35-64.

Alexandre, C. \& P. Almeida, 2010. The impact of small physical obstacles on the structure of freshwater fish assemblages. River Research and Applications Wiley Online Library 26: 977-994.

Alexiades, A. V. \& A. C. Encalada, 2017. Distribution and habitat suitability of andean climbing catfish in the Napo River Basin, Ecuador. Tropical Conservation Science 10: 1-7.

Alofs, K. M., E. A. Liverpool, D. C. Taphorn, C. R. Bernard \& H. López-Fernández, 2014. Mind the (information) gap: the importance of exploration and discovery for assessing conservation priorities for freshwater fish. Diversity and Distributions 20: 107-113.

Anderson, E. P. \& J. A. Maldonado-Ocampo, 2011. A regional perspective on the diversity and conservation of tropical Andean fishes. Conservation Biology 25: 30-39.
Araújo-Flores, J. M., J. Garate-Quispe, J. García Molinos, J. M. Pillaca-Ortiz, J. Caballero-Espejo, C. Ascorra, M. Silman \& L. E. Fernandez, 2021. Seasonality and aquatic metacommunity assemblage in three abandoned gold mining ponds in the southwestern Amazon, Madre de Dios (Peru). Ecological Indicators 125: 107455.

Arratia, F. G., 1983. Preferencias de habitat de peces siluriformes de aguas continentales de Chile (Fam. Diplomystidae y Trichomycteridae). Studies on Neotropical Fauna and Environment 18: 217-237.

Barrett, M., A. Belward, S. Bladen, T. Breeze, N. D. Burgess, S. H. M. Butchart, H. Clewlow, S. Cornell, A. Cottam, S. Croft, G. de Carlo, L. de Felice, A. De Palma, S. Deinet, R. Downie, C. Drijver, B. Fischler, R. Freeman, O. Gaffney, A. Galli, P. Gamblin, M. Garratt, N. Gorelick, J. Green, M. Grooten, L. Hanscom, S. L. L. Hill, C. H.- Taylor, A. Jones, T. Juniper, H. Khan, D. Kroodsma, D. Leclère, G. Llewellyn, G. Mace, L. McRae, K. Mo, J. Opperman, A. Orgiazzi, S. Orr, P. Pacheco, D. Palomares, D. Pauly, J.-F. Pekel, L. Pendleton, A. Purvis, N. Radcliffe, T. Roxburgh, B. Scholes, D. Senapathi, J. Tanzer, M. L. Thieme, D. Tickner, P. Tittonell, P. Trathan, P. Visconti, M. Wackernagel, C. West, \& N. Zwaal, 2018. Living Planet Report 2018: Aiming Higher. WWF, Gland, Switzerland.

Benejam, L., I. Tobes, S. Brucet \& R. Miranda, 2018. Size spectra and other size-related variables of river fish communities: systematic changes along the altitudinal gradient on pristine Andean streams. Ecological Indicators 90: 366-378.

Borcard, D., F. Gillet \& P. Legendre, 2011. Numerical Ecology with R, Springer, New York:

Borrelli, P., D. A. Robinson, L. R. Fleischer, E. Lugato, C. Ballabio, C. Alewell, K. Meusburger, S. Modugno, B. Schütt, V. Ferro, V. Bagarello, K. Van Oost, L. Montanarella \& P. Panagos, 2017. An assessment of the global impact of 21 st century land use change on soil erosion. Nature Communications 8: 2013.

Braak, C. J. F. F. \& P. F. M. M. Verdonschot, 1995. Canonical correspondence analysis and related multivariate methods in aquatic ecology. Aquatic Sciences 57: 255-289.

Buitrago-Suarez, U. A., J. I. Mojica-Corzo \& L. K. Bonneau, 2015. Habitat perturbation and survival strategies of the Andean catfish Astroblepus mariae (Fowler, 1919). Revista De La Academia Colombiana De Ciencias Exactas, Físicas y Naturales 39: 36.

Buytaert, W. \& B. De Bièvre, 2012. Water for cities: the impact of climate change and demographic growth in the tropical Andes. Water Resources Research 48: 8.

Carvajal-Quintero, J. D., F. Escobar, F. Alvarado, F. A. VillaNavarro, Ú. Jaramillo-Villa \& J. A. Maldonado-Ocampo, 2015. Variation in freshwater fish assemblages along a regional elevation gradient in the northern Andes, Colombia. Ecology and Evolution 5: 2608-2620.

Chará, J. D., D. J. Baird, T. C. Telfer \& E. A. Rubio, 2006. Feeding ecology and habitat preferences of the catfish genus Trichomycterus in low-order streams of the Colombian Andes. Journal of Fish Biology 68: 1026-1040.

Chiu, H.-P. \& J.-P. Suen, 2016. The importance of providing multiple-channel sections in dredging activities to improve fish habitat environments. Water 8: 36. 
Collen, B., M. Ram, T. Zamin \& L. Mcrae, 2008. The tropical biodiversity data gap: addressing disparity in global monitoring. Tropical Conservation Science 1: 75-88.

Cornejo, A., J. Pérez, N. López-Rojo, A. M. Tonin, D. Rovira, B. Checa, N. Jaramillo, K. Correa, A. Villarreal, V. Villarreal, G. García, E. Pérez, T. A. Ríos González, Y. Aguirre, F. Correa-Araneda \& L. Boyero, 2020. Agriculture impairs stream ecosystem functioning in a tropical catchment. Science of the Total Environment 745: 140950.

Costa, M. F. \& M. Barletta, 2016. Special challenges in the conservation of fishes and aquatic environments of South America. Journal of Fish Biology 89: 4-11.

Darwall, W. R. T., R. A. Holland, K. G. Smith, D. Allen, E. G. E. Brooks, V. Katarya, C. M. Pollock, Y. Shi, V. Clausnitzer, N. Cumberlidge, M. B. Seddon, P. H. Skelton, K. D. B. Dijkstra, M. D. Diop, N. García, J. Snoeks, D. Tweddle \& J.-C. Vié, 2011. Implications of bias in conservation research and investment for freshwater species. Conservation Letters 4: 474-482.

Donaldson, M. R., N. J. Burnett, D. C. Braun, C. D. Suski \& S. G. Hinch, 2016. Taxonomic bias and international biodiversity conservation research. Facets 1: 105-113.

DoNascimiento, C., E. E. Herrera-Collazos, G. A. Herrera-R, A. Ortega-Lara, F. A. Villa-Navarro, J. S. Usma Oviedo \& J. A. Maldonado-Ocampo, 2017. Checklist of the freshwater fishes of Colombia: a Darwin Core alternative to the updating problem. ZooKeys 708: 25-138.

Donin, L. M., J. Ferrer \& T. P. Carvalho, 2020. Taxonomical study of Trichomycterus (Siluriformes: Trichomycteridae) from the Ribeira de Iguape River basin reveals a new species recorded in the early 20th century. Journal of Fish Biology 96: 886-904.

Dudgeon, D., A. H. Arthington, M. O. Gessner, Z.-I. Kawabata, D. J. Knowler, C. Lévêque, R. J. Naiman, A.-H. PrieurRichard, D. Soto, M. L. J. Stiassny \& C. a Sullivan, 2006. Freshwater biodiversity: importance, threats, status and conservation challenges. Biological Reviews of the Cambridge Philosophical Society 81: 163-182.

Encalada, A. C., A. S. Flecker, N. L. Poff, E. Suárez, G. A. Herrera-R, B. Ríos-Touma, S. Jumani, E. I. Larson \& E. P. Anderson, 2019. A global perspective on tropical montane rivers. Science 365: 1124-1129.

Fischer, J., C. Paukert \& M. Daniels, 2012. Fish community response to habitat alteration: Impacts of sand dredging in the Kansas River. Transactions of the American Fisheries Society 141: 1532-1544.

Fricke, R., W. N. Eschmeyer, \& R. van der Laan, 2020. Eschmeyer's catalog of fishes: genera, species, references. [available on internet at Accessed 22 May 2020. http:// researcharchive.calacademy.org/research/ichthyology/ catalog/fishcatmain.asp].

Fu, C., J. Wu, J. Chen, Q. Wu \& G. Lei, 2003. Freshwater fish biodiversity in the Yangtze River basin of China: patterns, threats and conservation. Biodiversity and Conservation 12: $1649-1685$.

Gazendam, E., B. Gharabaghi, F. C. Jones \& H. Whiteley, 2011. Evaluation of the qualitative habitat evaluation Index as a planning and design tool for restoration of rural Ontario waterways. Canadian Water Resources Journal 36: $149-158$.
Giangrande, A., 2003. Biodiversity, conservation, and the "Taxonomic impediment." Aquatic Conservation: Marine and Freshwater Ecosystems 13: 451-459.

Grossman, G. D., R. E. J. Ratajczak, M. Crawford \& M. C. Freeman, 1998. Assemblage organisation in stream fishes: effects of environmental variation and interspecific interactions. Ecological Monographs 68: 395-420.

Hammer, Ø., D. A. T. Harper \& P. D. Ryan, 2001. PAST: paleontological statistics software package for education and data analysis. Palaeontologia Electronica 4: 1-9.

Hermoso, V., S. R. Januchowski-Hartley, S. Linke, D. Dudgeon, P. Petry \& P. McIntyre, 2017. Optimal allocation of Red List assessments to guide conservation of biodiversity in a rapidly changing world. Global Change Biology 23: 3525-3532.

Hermoso, V., A. F. Filipe, P. Segurado \& P. Beja, 2018. Freshwater conservation in a fragmented world: dealing with barriers in a systematic planning framework. Aquatic Conservation: Marine and Freshwater Ecosystems 28: $17-25$.

Herrera-R, G. A., T. Oberdorff, E. P. Anderson, S. Brosse, F. M. Carvajal-Vallejos, R. G. Frederico, M. Hidalgo, C. Jézéquel, M. Maldonado, J. A. Maldonado-Ocampo, H. Ortega, J. Radinger, G. Torrente-Vilara, J. Zuanon \& P. A. Tedesco, 2020. The combined effects of climate change and river fragmentation on the distribution of Andean Amazon fishes. Global Change Biology 26: 5509-5523.

Hubert, N. \& J. F. Renno, 2006. Historical biogeography of South American freshwater fishes. Journal of Biogeography 33: 1414-1436.

Jaramillo-Villa, Ú., J. A. Maldonado-Ocampo \& F. Escobar, 2010. Altitudinal variation in fish assemblage diversity in streams of the central Andes of Colombia. Journal of Fish Biology 76: 2401-2417.

Jézéquel, C., P. A. Tedesco, W. Darwall, M. S. Dias, R. G. Frederico, M. Hidalgo, B. Hugueny, J. MaldonadoOcampo, K. Martens, H. Ortega, G. Torrente-Vilara, J. Zuanon \& T. Oberdorff, 2020. Freshwater fish diversity hotspots for conservation priorities in the Amazon Basin. Conservation Biology 34: 956.

Jiménez-Prado, P., W. Aguirre, E. Laaz-Moncayo, R. Navarrete-Amaya, F. Nugra-Salazar, E. Rebolledo-Monsalve, E. Zárate-Hugo, A. Torres-Noboa, \& J. Valdiviezo-Rivera, 2015. Guía de peces para aguas continentales en la vertiente occidental del Ecuador. Pontificia Universidad Católica del Ecuador Sede Esmeraldas (PUCESE); Universidad del Azuay (UDA) y Museo Ecuatoriano de Ciencias Naturales (MECN) del Instituto Nacional de Biodiversidad, Esmeraldas, Ecuador.

Kriaučiūnienè, J., T. Virbickas, D. Šarauskienè, D. Jakimavičius, J. Kažys, A. Bukantis, V. Kesminas, A. Povilaitis, J. Dainys, V. Akstinas, A. Jurgelènaitè, D. MeilutytėLukauskienè \& A. Tomkevičienè, 2019. Fish assemblages under climate change in Lithuanian rivers. Science of the Total Environment 661: 563-574.

Latli, A., L. N. Michel, G. Lepoint \& P. Kestemont, 2019. River habitat homogenisation enhances trophic competition and promotes individual specialisation among young of the year fish. Freshwater Biology 64: 520-531.

Legendre, P. \& L. Legendre, 1998. Numerical Ecology, Elsevier, Amsterdam: 
Leitão, R. P., J. Zuanon, D. Mouillot, C. G. Leal, R. M. Hughes, P. R. Kaufmann, S. Villéger, P. S. Pompeu, D. Kasper, F. R. de Paula, S. F. B. Ferraz \& T. A. Gardner, 2018. Disentangling the pathways of land use impacts on the functional structure of fish assemblages in Amazon streams. Ecography 41: 219-232.

Lessmann, J., J. M. Guayasamin, K. L. Casner, A. S. Flecker, W. C. Funk, C. K. Ghalambor, B. A. Gill, I. Jácome-Negrete, B. C. Kondratieff, L. N. Poff, J. Schreckinger, S. A. Thomas, E. Toral-Contreras, K. R. Zamudio \& A. C. Encalada, 2016. Freshwater vertebrate and invertebrate diversity patterns in an Andean-Amazon basin: implications for conservation efforts. Neotropical Biodiversity 2: 99-114.

Lessmann, J., M. J. Troya, A. S. Flecker, W. W. ChrisFunk, J. M. Guayasamin, V. Ochoa-Herrera, N. L. Poff, E. Suárez \& A. C. Encalada, 2019. Validating anthropogenic threat maps as a tool for assessing river ecological integrity in Andean-Amazon basins. PeerJ 2019: 1-23.

Li, J., L. Huang, L. Zou, Y. Kano, T. Sato \& T. Yahara, 2011. Spatial and temporal variation of fish assemblages and their associations to habitat variables in a mountain stream of north Tiaoxi River, China. Environmental Biology of Fishes 93: 403-417.

Liang, L., S. Fei, J. B. Ripy, B. L. Blandford \& T. Grossardt, 2013. Stream habitat modelling for conserving a threatened headwater fish in the upper Cumberland River, Kentucky. River Research and Applications 29: 1207-1214.

Linke, S., B. Lehner, C. Ouellet Dallaire, J. Ariwi, G. Grill, M. Anand, P. Beames, V. Burchard-Levine, S. Maxwell, H. Moidu, F. Tan \& M. Thieme, 2019. Global hydro-environmental sub-basin and river reach characteristics at high spatial resolution. Scientific Data 6: 283.

López-Delgado, E. O., K. O. Winemiller \& F. A. Villa-Navarro, 2020. Local environmental factors influence beta-diversity patterns of tropical fish assemblages more than spatial factors. Ecology 101: 1-12.

Lujan, N. K., K. A. Roach, D. Jacobsen, K. O. Winemiller, V. M. Vargas, V. R. Ching \& J. A. Maestre, 2013. Aquatic community structure across an Andes-to-Amazon fluvial gradient. Journal of Biogeography 40: 1715-1728.

Mace, G. M., 2004. The role of taxonomy in species conservation. Philosophical Transactions of the Royal Society B: Biological Sciences 359: 711-719.

Maldonado-Ocampo, J. A., A. Ortega-Lara, J. S. Usma, G. Galvis, F. A. Villa-Navarro, L. Vásquez, S. Prada-Pedreros, \& C. Ardila, 2005. Peces de los Andes de Colombia. Instituto de Investigación de Recursos Biológicos Alexander von Humboldt, Bogotá D.C.

Meador, M. R., J. McIntyre \& K. Pollock, 2003. Assessing the efficacy of single-pass backpack electrofishing to characterise fish community structure. Transactions of the American Fisheries Society 132: 39-46.

Miqueleiz, I., M. Bohm, A. H. Ariño \& R. Miranda, 2020. Assessment gaps and biases in knowledge of conservation status of fishes. Aquatic Conservation: Marine and Freshwater Ecosystems 30: 225-236.

Miranda, R., I. Tobes, S. Gaspar \& M. Peláez-Rodríguez, 2018. Patterns in the distribution of fish assemblages and their association with habitat variables in the Suaza River on its way through the Cueva de los Guácharos National Park, Colombia. Écoscience 25: 85-95.

Moody, E. K., N. K. Lujan, K. A. Roach \& K. O. Winemiller, 2019. Threshold elemental ratios and the temperature dependence of herbivory in fishes. Functional Ecology 33: 913-923.

Morabowen, A., V. Crespo-Pérez \& B. Ríos-Touma, 2019. Effects of agricultural landscapes and land uses in highly biodiverse tropical streams of the Ecuadorian Choco. Inland Waters 9: 289-300.

Munné, A., N. Prat, C. Solà, N. Bonada \& M. Rieradevall, 2003. A simple field method for assessing the ecological quality of riparian habitat in rivers and streams: QBR index. Aquatic Conservation: Marine and Freshwater Ecosystems 13: $147-163$.

Oberdorff, T., M. S. Dias, C. Jézéquel, J. S. Albert, C. C. Arantes, R. Bigorne, F. M. Carvajal-Vallejos, A. De Wever, R. G. Frederico, M. Hidalgo, B. Hugueny, F. Leprieur, M. Maldonado, J. A. Maldonado-Ocampo, K. Martens, H. Ortega, J. Sarmiento, P. A. Tedesco, G. Torrente-Vilara, K. O. Winemiller \& J. A. S. Zuanon, 2019. Unexpected fish diversity gradients in the Amazon basin. Science Advances 5: eaav8681.

Olden, J. D., M. J. Kennard, F. Leprieur, P. A. Tedesco, K. O. Winemiller \& E. García-Berthou, 2010. Conservation biogeography of freshwater fishes: recent progress and future challenges. Diversity and Distributions 16: 496-513.

Pelayo-Villamil, P., C. Guisande, R. P. Vari, A. ManjarrésHernández, E. García-Roselló, J. González-Dacosta, J. Heine, L. González Vilas, B. Patti, E. M. Quinci, L. F. Jiménez, C. Granado-Lorencio, P. A. Tedesco \& J. M. Lobo, 2015. Global diversity patterns of freshwater fishes - potential victims of their own success. Diversity and Distributions 21: 345-356.

Pelicice, F. M., V. M. Azevedo-Santos, J. R. S. Vitule, M. L. Orsi, D. P. Lima Junior, A. L. B. Magalhães, P. S. Pompeu, M. Petrere \& A. A. Agostinho, 2017. Neotropical freshwater fishes imperilled by unsustainable policies. Fish and Fisheries 18: 1119-1133.

Pouilly, M., S. Barrera \& C. Rosales, 2006. Changes of taxonomic and trophic structure of fish assemblages along an environmental gradient in the Upper Beni watershed (Bolivia). Journal of Fish Biology 68: 137-156.

Prudente, B. S., P. S. Pompeu, L. Juen \& L. F. A. Montag, 2017. Effects of reduced-impact logging on physical habitat and fish assemblages in streams of Eastern Amazonia. Freshwater Biology 62: 303-316.

Quist, M. C., W. A. Hubert \& D. J. Isaak, 2004. Fish assemblage structure and relations with environmental conditions in a Rocky Mountain watershed. Canadian Journal of Zoology 82: 1554-1565.

Ramankutty, N., A. T. Evan, C. Monfreda \& J. A. Foley, 2008. Farming the planet: 1. Geographic distribution of global agricultural lands in the year 2000. Global Biogeochemical Cycles 22: 1-19.

Reid, A. J., A. K. Carlson, I. F. Creed, E. J. Eliason, P. A. Gell, P. T. J. Johnson, K. A. Kidd, T. J. MacCormack, J. D. Olden, S. J. Ormerod, J. P. Smol, W. W. Taylor, K. Tockner, J. C. Vermaire, D. Dudgeon \& S. J. Cooke, 2019. Emerging threats and persistent conservation challenges for freshwater biodiversity. Biological Reviews 94: 849-873. 
Reis, R. E., 2013. Conserving the freshwater fishes of South America. International Zoo Yearbook 47: 65-70.

Reis, R. E., J. S. Albert, F. Di Dario, M. M. Mincarone, P. Petry \& L. A. Rocha, 2016. Fish biodiversity and conservation in South America. Journal of Fish Biology 89: 12-47.

Richardson, J. S., 2019. Biological diversity in headwater streams. Water (switzerland) 11: 1-19.

Ríos-Touma, B. \& A. Ramírez, 2019. Multiple stressors in the Neotropical region: environmental impacts in biodiversity hotspots. In Elosegi, A. \& R. Ludwig (eds), Multiple Stressors in River Ecosystems Elsevier, Amsterdam: 205-220.

Rodrigues-Filho, C. A. S., R. C. Gurgel-Lourenço, S. M. Q. Lima, E. F. de Oliveira \& J. I. Sánchez-Botero, 2017. What governs the functional diversity patterns of fishes in the headwater streams of the humid forest enclaves: environmental conditions, taxonomic diversity or biotic interactions? Environmental Biology of Fishes Environmental Biology of Fishes 100: 1023-1032.

Román-Valencia, C., 2001. Ecología trófica y reproductiva de Trichomycterus caliense y Astroblepus cyclopus (Pisces: Siluriformes) en el río Quindio, Alto Cauca, Colombia. Revista De Biologia Tropical 49: 657-666.

Schaefer, S. A. \& J. Arroyave, 2010. Rivers as islands: determinants of the distribution of Andean astroblepid catfishes. Journal of Fish Biology 77: 2373-2390.

Simonson, T. D., J. Lyons \& P. D. Kanehl, 1994. Quantifying fish habitat in streams: transect spacing, sample size, and a proposed framework. North American Journal of Fisheries Management 14: 607-615.

Tejerina-Garro, F. L., M. Maldonado, C. Ibañez, D. Pont, N. Roset \& T. Oberdorff, 2005. Effects of natural and anthropogenic environmental changes on riverine fish assemblages: a framework for ecological assessment of rivers. Brazilian Archives of Biology and Technology 48: 91-108.

Tisseuil, C., J.-F. Cornu, O. Beauchard, S. Brosse, W. R. T. Darwall, R. Holland, B. Hugueny, P. A. Tedesco \& T. Oberdorff, 2013. Global diversity patterns and cross-taxa convergence in freshwater systems. Journal of Animal Ecology 82: 365-376.

Tobes, I., S. Gaspar, J. Oscoz \& R. Miranda, 2016a. Diagnosing stream ecosystem integrity in the Ordesa-Viñamala Biosphere Reserve, central Spanish Pyrenees. Journal of Applied Ichthyology 32: 229-239.
Tobes, I., S. Gaspar, M. Peláez-Rodríguez \& R. Miranda, 2016 b. Spatial distribution patterns of fish assemblages relative to macroinvertebrates and environmental conditions in Andean piedmont streams of the Colombian Amazon. Inland Waters 6: 89-104.

Tognelli, M. F., E. P. Anderson, L. F. Jiménez-Segura, J. Chuctaya, L. Chocano, J. A. Maldonado-Ocampo, L. Mesa-Salazar, J. I. Mojica, F. M. Carvajal-Vallejos, V. Correa, H. Ortega, J. F. Rivadeneira Romero, P. SánchezDuarte, N. A. Cox, M. Hidalgo, P. Jiménez Prado, C. A. Lasso, J. Sarmiento, M. A. Velásquez \& F. A. VillaNavarro, 2019. Assessing conservation priorities of endemic freshwater fishes in the Tropical Andes region. Aquatic Conservation: Marine and Freshwater Ecosystems 29: 1123-1132.

Vélez-Espino, L. A., 2003. Taxonomic revision, ecology and endangerment categorisation of the Andean catfish Astroblepus ubidiai (Teleostei: Astroblepidae). Reviews in Fish Biology and Fisheries 13: 367-378.

Vélez-Espino, L. A., 2005. Population viability and perturbation analyses in remnant populations of the Andean catfish Astroblepus ubidiai. Ecology of Freshwater Fish 14: 125-138.

Vélez-Espino, L. A., 2006. Distribution and habitat suitability index model for the Andean catfish Astroblepus ubidiai (Pisces: Siluriformes) in Ecuador. Revista De Biologia Tropical 54: 623-638.

Venter, O., E. W. Sanderson, A. Magrach, J. R. Allan, J. Beher, K. R. Jones, H. P. Possingham, W. F. Laurance, P. Wood, B. M. Fekete, M. A. Levy \& J. E. M. Watson, 2016. Global terrestrial human footprint maps for 1993 and 2009. Scientific Data 3: 1-10.

Vimos, D. J., A. C. Encalada, B. Ríos-Touma, E. Suárez \& N. Prat, 2015. Effects of exotic trout on benthic communities in high-Andean tropical streams. Freshwater Science 34: 770-783.

Warton, D. I. \& F. K. C. Hui, 2011. The arcsine is asinine: the analysis of proportions in ecology. Ecology 92: 3-10.

Publisher's Note Springer Nature remains neutral with regard to jurisdictional claims in published maps and institutional affiliations. 